\title{
Internationalisation of Portuguese Higher Education: challenges and opportunities
}

\author{
Mónica Lourenço, Susana Pinto \\ \& Betina Silva-Lopes
}

\section{Rationale}

The world of today is rapidly changing and increasingly global - local conditions have become global concerns and local actions have global repercussions. This global world has been placing numerous challenges to Higher Education Institutions (HEI), who are asked to increase their attractiveness to international students and staff; to offer new modalities of teaching and learning more in tune with the current technological developments and requirements; to overcome competition to achieve the highest positions in international rankings; and to become key players in the global economy, contributing not only to the knowledge stock of the world, but also to the financial economy of their countries (Maringe \& Foskett, 2010; Wihlborg \& Robson, 2018).

This global world also requires a new set of skills, knowledge and dispositions from people. Therefore, universities are called upon to develop international and intercultural competences and to foster critical thinking, creativity and collaboration, in order to prepare students and staff to work together to find solutions to the world's most pressing issues and contribute to more sustainable and inclusive societies. In brief, HEI are "at the forefront of these changes in ways that can benefit not only nations and regions but also individuals within them" (Ryan, 2013, p. 3). 
Recognising the challenges of globalisation and the requirement to adapt, no longer slowly but in quantum leaps, to new realities, HEl have turned to internationalisation as both a response and a proactive way of meeting these demands. Universities, whether large or small and irrespective of their market position, work to become global institutions involved in and leading world-class research at the cutting edge, drawing the highest calibre students and staff from different parts of the world, and focusing on scientific and social issues of global significance. Some HEl have also begun to recognise the importance of developing teaching programmes that have local and international relevance, both to place students in a global market and to prepare them for life as global citizens (Yemini, 2017).

Over the last decade, Portugal has also increased investment in the internationalisation of its HEl. This investment was a response to the demands of the implementation of the Bologna Process, the pressure of the European Union to promote a European Higher Education Area, and the need to boost enrolment of international students to overcome the economic and demographic crises (França, Alves \& Padilla, 2018). According to Guerreiro (2015), Portuguese HEl have adopted several internationalisation strategies that range from mobility of the academic community, the attraction of international students, foreign teachers and researchers, adoption of double/joint degrees and support to international scientific collaboration, to the creation of an international environment on campus (for instance, through initiatives such as welcome packages and intercultural events). Worthy of note in the internationalisation of Portuguese HEl are also the rapid growth of English-medium instruction, understood as a means to attract foreign students and faculty so as to have a competitive profile and achieve the highest positions in international rankings (Lourenço \& Pinto, 2019), and investment in international cooperation for development programmes, namely with Portuguesespeaking countries (Ferreira, Faria, \& Cardoso, 2015; Silva-Lopes, Albergaria-Almeida, Costa, \& Callapez, 2016).

Still, despite the financial and legislative incentive of European institutions, the early days of the internationalisation of Portuguese higher education were characterised by the development of isolated and seemingly disorganised measures, which have led to modest results when we consider the resources that were invested (Veiga, Rosa \& Amaral, 2006). In response to this, and following European guidelines (EC, 2013), in 2014, the Ministry of Education and Science and the Ministry for Regional Development created a working group to define a coherent national internationalisation strategy for Portuguese higher education. The report $A$ strategy for the internationalisation of Portuguese Higher Education (MES, 2014), approved in 2015 by the Council of Ministers Resolution 47/2015 of the 14th July, presents a set of recommendations focusing on inter-institutional collaboration (joint degrees and international consortia), mobility, foreign language proficiency, and branding. The document underlines that "university 
education in Portugal benefits from two particular conditions that derive from the two international spaces in which Portugal is integrated: the European Union and the Community of Portuguese Language Countries (CPLP)" (MES, 2014, p. 11), emphasising the key role of English and Portuguese languages. Also in 2014, Decree Law 36/2014 was published which defined the International Student Status and a new access regime, although maintaining the previous special regime for students benefiting from scholarships from the Portuguese government and coming from Portuguese-speaking African countries and East Timor. This document created the necessary legal mechanisms to reinforce the capacity of Portuguese HEl to attract international students, contributing to the implementation of planned and concerted institutional recruitment strategies.

The internationalisation policy of HEl increased pace in 2016 with the publication of Resolution 78/2016 of the Council of Ministers, which defines guidelines aiming at the articulation between the internationalisation policy of higher education, science and technology with other public internationalisation policies. This Resolution, which perceives $\mathrm{HEl}$ as privileged spaces for knowledge creation and dissemination contributing to social, cultural and economic development, gave rise to the platform Study \& Research in Portugal, launched in 2016 by the Ministry for Science, Technology and Higher Education, together with the Directorate General for Higher Education, the Foundation for Science and Technology, the Secretary of State for Tourism, and Tourism of Portugal. This digital platform was conceived as an instrument for the promotion and internationalisation of the country, in areas such as education, science and technology, scientific diplomacy, tourism, mobility, economy, language and culture.

Against this background and acknowledging the challenges and opportunities faced by $\mathrm{HEl}$ in what internationalisation is concerned, the Research Centre on Didactics and Technology in the Education of Trainers (CIDTFF) organized an international Seminar entitled Educating for a global world: challenges and opportunities for Portuguese Higher Education Institutions (http://seminariointernacionalizao.web.ua.pt/ index.php/en/context/), which took place at the University of Aveiro on the $19^{\text {th }}$ and $20^{\text {th }}$ October 2017. The Seminar focused on different facets of internationalisation in Portuguese Higher Education, namely: (i) internationalisation of the curriculum and internationalisation at home, (ii) language policy and internationalisation, and (iii) international cooperation for development in teacher education. Organized around these three thematic strands, the event allowed researchers, academics, institutional stakeholders and students to share and discuss the challenges and opportunities that internationalisation poses to Portuguese $\mathrm{HEI}$.

The positive response and interest of the academic and scientific community on these issues, alongside the need to bring together a seemingly scattered but valuable research and practice, validate the relevance of this thematic dossier, which has 
two main aims: (i) to provide readers with an understanding of how Portuguese HEI and institutional actors (such as governing and coordinating bodies, academic and non-academic staff, and students) are facing challenges and opportunities posed by internationalisation; and (ii) to give insights into possible pathways for a more comprehensive, holistic and sustainable integration of the international dimension into teaching and learning, research, and cooperation in higher education.

\section{Structure}

This thematic dossier brings together seven papers exploring challenges and opportunities posed by internationalisation to Portuguese HEl and related to different issues: the need to develop a comprehensive internationalisation approach with greater impact on student learning; the importance of carrying out articulated institutional strategies to recruit international students, capitalising on the advantages offered by the Portuguese language; the relevance of Internationalization at Home approaches in the classroom to promote students' professional competence; the need for HEl to acknowledge the role of languages in their internationalisation strategies and to develop (multilingual) institutional language policies for education and research; and the importance of investing in a dialogic cooperation in the context of international cooperation for development.

The dossier opens with a text by Mónica Lourenço, Ana Isabel Andrade and Michael Byram who focus on the social representations of internationalisation at a Portuguese public university present in institutional and stakeholders' discourses. Drawing on thematic analysis of institutional policy documents and semi-structured interviews conducted with members of governing and coordinating bodies, as well as with academic and non-academic staff, the authors conclude that internationalisation is understood as a strategic priority related with activities such as student mobility and English-medium instruction, and with a set of desired outcomes, namely the need to increase revenues and get more visibility. Academic staff also tend to consider internationalisation a valuable asset for the development of students' skills, expressing positive attitudes towards such initiatives as Internationalisation at Home. Based on these findings, the authors suggest a set of recommendations for a more comprehensive and sustainable internationalisation approach applicable to other institutional contexts.

Moving from representations to strategies, Cristina Sin, Sónia Cardoso and Orlanda Tavares, analyse one of the most prevalent internationalisation strategies adopted by $\mathrm{HEI}$ - the recruitment of international students. The authors start by analysing national policies and then focus on the strategies developed by two universities in order to understand how Portugal, in general, and national HEl, in particular, are competing against more attractive destinations. At national level, the paper shows that there has been an increasing political interest in internationalisation, namely by defining measures 
aimed at recruiting international students. At the institutional level, the study highlights that although both universities lack articulated recruitment policies, they have been implementing some strategies - institutional branding, review of admission procedures and curricular adaptation -, capitalising on the advantages offered by the Portuguese language with an emphasis on attracting Lusophone and Chinese students.

Staying within the topic of internationalisation strategies, Belém Barbosa, Claudia Santos and Claudia Prado-Meza present the results of two initiatives carried out in 2016 within an Internationalisation at Home perspective: a 4-week intercontinental online collaboration between Portugal and Mexico, and activities conducted throughout one semester in a multicultural classroom. These initiatives involved a total of 70 students in Business and Marketing courses. The results, based on qualitative observations and focus groups, indicate positive impact on the students involved, namely concerning motivation, satisfaction and development of professional competences.

Language policy in Portuguese Higher Education is the theme of the following two papers of the thematic dossier. Susana Pinto and Maria Helena Araújo e Sá present a study focused on Portuguese public universities which identified and discussed institutional stakeholders' beliefs concerning language teaching/learning in higher education, the use of languages in research and the development of institutional language policies. Besides showing similar tendencies regarding beliefs, the findings evidence a tension between reported practices, which centre on "English-mainly", and the recognition of the need to develop institutional multilingual language policies for education and research. The authors present some guidelines addressed at Portuguese HEI and aiming at the development of language policies based on a complementary institutional multilingualism as a less obvious strategy for internationalisation.

Gillian Moreira addresses the capacity of languages to act as both gateway and obstacle to the internationalisation of higher education, focusing on the importance attributed to internationalisation and language strategies applied by the University of Aveiro in the period 2010-2018. For this matter, the author analysed institutional policy documents and concluded that internationalisation is a priority for the institution and that although there is a strong commitment to increasing English-medium instruction, a balance between Portuguese and English is sought in institutional language policies. Moreover, the findings show that other foreign languages are considered assets for the institution and its actors, namely for students.

The two final papers of the thematic dossier revolve around Portuguese HEl as development actors. Betina Silva-Lopes presents the results of a sequential mixed methods study that discusses the work undertaken by Portuguese Public Universities (PPU) as development actors, particularly in the field of Science Education in the six Portuguese-speaking countries from the ACP region (Angola, Cape Verde, GuineaBissau, Mozambique, São Tomé and Príncipe and East Timor). The study involved 
documental analysis of 189 protocols established between 2000 and 2015, as well as semi-structured interviews with institutional actors. The results point to a prominent role of PPU in the field of Science Education, particularly in teacher training. The importance of investing in training and dissemination strategies in the domain of international cooperation for development is highlighted.

Within the same theme, Nilza Costa and Bernardo Filipe Matias write about a specific international cooperation experience involving two Angolan master courses (Science Education and Curricular Development). Sustaining their study on the importance of a situated epistemology, potentialities and constraints associated to a protocol involving one Angolan higher education institution and three public Portuguese universities are discussed. Moreover, specific recommendations considering future international collaboration on teacher education are presented.

As invited editors of this thematic dossier, we would like to thank all the people who made this publication possible: the contributors, for sharing their knowledge and research experiences; the corps of peer reviewers who provided rigorous and constructive comments to the manuscripts and which were essential to improve the quality of this thematic dossier; the editorial team of Revista Lusófona de Educação for acknowledging the relevance of this thematic dossier and accepting our publication project; to CIDTFF, our research centre, for supporting us in this endeavour.

\section{Acknowledgement}

This work is financially supported by National Funds through FCT - Fundação para a Ciência e a Tecnologia, I.P. under the project UIDB/00194/2020.

\section{References}

European Commission. (2013). European Higher Education in the World. Brussels: European Commission.

França, T., Alves, E., \& Padilla, B. (2018). Portuguese policies fostering international student mobility: a colonial legacy or a new strategy? Globalisation, Societies and Education, 1-14.

Ferreira, P., Faria, F., \& Cardoso, F. (2015). O papel de Portugal na arquitectura global do desenvolvimento: opções para o futuro da Cooperação Portuguesa. Lisboa: IMVF \& ECDPM.

Guerreiro, C. (2015). A internacionalização do ensino superior português as razões, as estratégias e os desafios (Dissertação de mestrado). Porto: Instituto Politécnico do Porto.

Knight, J. (2012). Five truths about internationalization. International Higher Education, 69, 1-4.

Lourenço, M., \& Pinto, S. (2019). Expatriate and home teachers' beliefs about English-medium instruction at a Portuguese university. European Journal of Higher Education, 9(3), 252-267.

Maringe, F., \& Foskett, N. (2010). Introduction: Globalization and universities. In F. Maringe \& N. Foskett (Eds.), Globalization and internationalization in higher education: theoretical, strategic and management perspectives (pp. 1-13). London: Continuum. 
Ministry of Education and Science. (2014). A strategy for the internationalisation of Portuguese Higher Education. Lisbon: MES.

Ryan, J. (2013). Introduction. In J. Ryan (Ed.), Cross-cultural teaching and learning for home and international students: internationalisation of pedagogy and curriculum in higher education (pp. 1-12). Abingdon: Routledge.

Silva-Lopes, B., Albergaria-Almeida, P., Costa, N., \& Callapez, P. (2016). Cooperação para o desenvolvimento no âmbito da Educação em Ciências - estudo das atividades protocoladas entre Portugal e países africanos de língua oficial portuguesa. In Livro de Atas do Fórum Internacional África, Cooperação, Educação e Desenvolvimento (pp. 81-89). Penafiel: Instituto Superior de Ciências Educativas do Douro.

Veiga, A., Rosa, M., \& Amaral, A. (2006). The internationalisation of Portuguese higher education: how are higher education institutions facing this challenge? Higher Education Management, 18(1), 113128.

Wihlborg, M., \& Robson, S. (2018). Internationalisation of higher education: drivers, rationales, priorities, values and impacts. European Journal of Higher Education, 8(1), 8-18.

Mónica Lourenço, Susana Pinto \& Betina Silva-Lopes 